\title{
LITERÁRNÍ PRAMENY K ŘECKÉ MEDICÍNĚ PREHISTORICKÉHO A „TEMNÉHO“ OBDOBÍ (DO ROKU 600 PŘ. KR.) ${ }^{1}$
}

\author{
TOMÁŠ ALUŠÍK
}

\section{LITERARY SOURCES ON GREEK MEDICINE OF PREHISTORIC ERA AND THE 'DARK' AGE (BEFORE 600 BCE)}

The aim of this contribution is to present and discuss literary sources pertaining to the development of Greek medicine in the prehistoric period (the Bronze Age, mainly the second millennium BCE) and the so-called Dark Age (from $1050 \mathrm{BCE}$ until $600 \mathrm{BCE}$ ). Very few literary sources on Greek medicine of this period survive. From the Bronze Age, there are several texts, surviving mainly on clay tablets, which were written in syllabic, linear scripts A and B. From the Dark Age, one can draw some amount of information about medical knowledge and healing from works of art (poetry), mainly from Homeric epics. And while this information is fragmentary, it does enable us to understand and reconstruct some details pertaining not only to the medical practices, therapeutic methods, and even physicians and their assistants, but also about religious ideas linked to health and healing at the time.

Keywords: medicine - Greece - prehistory - Dark Age - Linear A - Linear B - Homeric epic

DOI: $10.14712 / 23365730.2018 .18$

\section{1. Úvod}

Nejvíce pramenů pro dějiny řeckého lékařství do roku 600 př. Kr. je získáváno archeologicky. Jde především o antropologický kosterní materiál, který nás informuje o zdravotním stavu (příznaky nemocí a traumat dochovaných na kostech) a (prostřednictvím analýz stabilních izotopů kostní tkáně) o převládající výživě dotčené populace. Mezi další archeologické prameny patří napřr. lékařské nástroje, nádoby s dochovanými zbytky (tzv. rezidui) léčivých prostředků a také umělecká zobrazení, na nichž jsou zachyceny lékařské výkony nebo božstva mající vztah k medicíně (nejčastěji se jedná o malby na keramice a volnou plastiku, včetně reliéfu). Naproti tomu literárních pramenů se dochovalo jen malé množství. Chronologicky nejvíce nálezů-pramenů pochází z doby bronzové (zejména z jejích pokročilých fází, od 2. tisíciletí př. Kr.) a následujícího „temného“ období.

1 Prehistorické období v Řecku zahrnuje dobu kamennou a bronzovou. Přechod mezi neolitem (mladší dobou kamennou) a dobou bronzovou nastal v závěru 4. tisíciletí př. Kr. a přechod k době železné ve 12.-11. století př. Kr. Jako konec doby bronzové bývají většinou stanoveny roky 1075/1050 př. Kr. (viz např. Eric H. CLiNE /ed./, The Oxford Handbook of the Bronze Age Aegean /ca. 3000-1000 BC/, Oxford 2010, s. 18-24). Tzv. temné období v tomto příspěvku zahrnuje dobu protogeometrickou (1050-900 př. Kr.), geometrickou (900-700 přr. $\mathrm{Kr}$.) a orientalizující (7. století př. Kr.). 


\section{Literární prameny}

Literárních pramenů $\mathrm{k}$ dějinám řecké medicíny sledovaného období je velice málo. Z prehistorického období jde o několik textů (především na hliněných tabulkách) zapsaných ve slabičných, tzv. lineárních písmech $\mathrm{A}$ a $\mathrm{B}$. Zatímco lineární písmo $\mathrm{A}$, doložené na Krétě v období nových paláců (archeologické fáze středně mínojská IIIB - pozdně mínojská IB, asi od konce 18. do 1. poloviny 15 . století př. Kr.), je stále prakticky nerozluštěné (některé jeho znaky dovedeme přečíst na základě pozdějších analogií, ale jazyk zůstává dosud neznámý), ${ }^{2}$ lineární písmo $\mathrm{B}$ (vyskytující se na řecké pevnině i na Krétě ve fázích pozdně heladská/mínojská IIIA-B, zhruba 14.-13. století př. Kr.) zachycuje nejstarší známou formu řečtiny. ${ }^{3}$ Záznamy psané těmito lineárními písmy však mají ryze hospodářský, respektive administrativní charakter. Bohužel tedy chybí vlastní lékařské texty, jaké známe třeba z prehistorického Egypta (např. lékařské papyry, mezi nejznámější patř́ tzv. Ebersův papyrus). ${ }^{4} \mathrm{~V}$ průběhu „temného“ období se objevují první skutečná umělecká literární díla. Určité množství informací o lékařských znalostech i léčení v „temném obdobi““ lze čerpat $\mathrm{z}$ homérských eposů. $\mathrm{V}$ tomto př́spěvku ale nebudou diskutovány umělecké kvality jednotlivých literárních děl $\mathrm{a}-\mathrm{v}$ prrípadě homérských eposů a hymnů - ani otázky jejich přesné chronologie, autorství, historické věrohodnosti atp. Bude zde zmíněn pouze jejich význam a prínos pro studium dějin lékařství sledovaného období.

\subsection{Prehistorické literární prameny}

Nejstarším literárním pramenem pro dějiny prehistorické řecké medicíny může být nápis na velké nádobě (pithos) z Faistu na Krétě, provedený v lineárním písmu A z archeologické fáze pozdně mínojská IA ${ }^{5}$ (17. století př. Kr.). Jedna hypotéza navrhuje čtení jako „si-ma

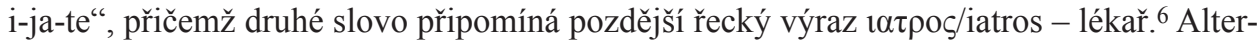
nativní hypotéza ale čte nápis jednoduše jako „od/patř́íi i-ja“.7

Mnohem důležitějǐím pramenem jsou však tabulky popsané lineárním písmem $B$, především několik z nich nalezených v Pylu a v Mykénách na Peloponéském poloostrově

2 Viz např. Godart - Olivier 1976, 1979, 1982, 1985: Louis GodART - Jean-Pierre OlIVIER, Recueil des inscriptions en Linéaire A, vol. 1. Tablettes éditées avant 1970, Paris 1976; Tíz̆, Recueil des inscriptions en Linéaire A, vol. 3, Tablettes, nodules et rondelles édités en 1975 et 1976, Paris 1976; Tíž, Recueil des inscriptions en linéaire A, vol 2: nodules, scellés et rondelles édités avant 1970, Paris 1979; Tíž, Recueil des inscriptions en linéaire A, vol. 4: Autres documents, Paris 1982; tíž (eds.), GORILA 5: addenda, corigenda, concordances, index et planches des signes, Paris 1985; Helena Tomas, Cretan Hieroglyphic and Linear A, in: Eric H. Cline (ed.), The Oxford Handbook, s. 340-355.

3 Viz např. Michael Ventris - John CHADwick, Documents in Mycenaean Greek, Cambridge 1973; James T. HoOKER, Linear B: An Introduction, Bristol 1980; Thomas G. PALAIMA, The Scribes of Pylos, Roma 1988; TÝž, Linear B, in: Eric H. Cline (ed.), The Oxford Handbook, s. 356-372; Yves Duhoux - Anna Morpurgo DavieS (eds.), A Companion to Linear B: Mycenaean Greek Texts and their World, I, Leuven 2008; tíž (eds.), A Companion to Linear B: Mycenaean Greek Texts and their World, II, Leuven 2011; tíž (eds.), A Companion to Linear B: Mycenaean Greek Texts and their World, III, Leuven 2014.

4 Viz např. Cyril P. BRYAn, The Papyrus Ebers, London 1930.

5 Nápis PH Zb 4, viz např. L. Godart - J.-P. Olivier, GORILA 4, s. 93.

6 Gareth A. Owens - G. Trench, A Possible Reading of Linear A PH Zb 4, Kadmos 35, 1996, s. 171-172.

7 John G. Younger, Food Rations and Portions in Cretan Hieroglyphic Documents, in: Louise A. HitchcockRobert Laffineur - Janice Crowley (eds.), Dais: The Aegean Feast. Proceedings of the 12th International Aegean Conference / 12e Rencontre égéenne internationale, University of Melbourne, Centre for Classics and Archaeology, 25-29 March 2008, Liège - Austin 2008, s. 361-365. 
a v Knóssu na Krétě. Z Pylu pocházejí tabulky Py Eq 146, Py Vn 1314, Py Vn 130, Py Aa 815 a Py Jn 832. Všechny jsou datovány do doby destrukce tamního paláce v archeologické fázi pozdně helladská IIIB2 (zhruba 2. polovina 13. století př. Kr.). Tabulka Py Eq $146^{8}$ byla objevena v tzv. Archivním komplexu (Archive Complex, Archive Room 7) a popsal ji písař označovaný jako Scribe 74, Hand 1 . Z hlediska dějin lékařství jsou nejdůležitější dva řádky (č. 9 a 10) jinak poměrně dlouhého textu (o celkem patnácti řádcích). Na řádku 9 jsou napsána slova ,[...]me-no i-ja-te“. To druhé z nich (i-ja-te) bývá všeobecně považováno za předchůdce pozdějšího slova $\imath \tau \imath \eta ́ \rho / \imath \alpha \tau \eta ́ \rho$, respektive v klasické řečtině $1 \alpha \tau \rho o \varsigma$ (iatros) neboli lékař. Dohromady se na řádcích 9 a 10 dozvídáme, že ,i-ja-te“ vlastnil určitou plochu půdy a navíc dostával každoročně 96 litrů obilí. Slovo ,[...]me-no“ je pravděpodobně část lékařova jména. $V$ takovém případě by se jednalo o jednoho ze dvou nejstarších jménem známých řeckých a vůbec evropských lékařů (viz níže). Na této tabulce je tedy literárně poprvé bezpečně doložena existence lékaře v sociálním a ekonomickém smyslu, ale bohužel ne v tom pracovním. Není tedy jisté, zda šlo o jeho jedinou profesi - zda pracoval jako lékař na plný úvazek. Text na tabulce je pouze záznamem jeho pozemkové držby, patrně odměny za jeho služby. Vzhledem k tomu, že plocha jeho půdy nebyla nikterak velká, znamenalo by to, že šlo pouze o jednoho z mnoha specializovaných řemeslníků. Nabízí se ale lákavá myšlenka, že na své půdě mohl pěstovat (mimo jiné?) léčivé byliny. Na tabulce Py Aa $815^{9}$ (rovněž nalezené v Archivním komplexu) je zapsáno slovo „a-ke-ti-ra“, které bylo původně interpretováno jako zdravotní sestra, pečovatelka, př́padně porodní bába, ${ }^{10}$ ale z kontextu vyplývá, že se jedná o osoby spjaté s textilní produkcí (konkrétně tedy jde spíše o přadlenu). ${ }^{11}$ Hned na prvním řádku tabulky Py Jn 832, ${ }^{12}$ nalezené opět v Archivním komplexu, lze přečíst slovo ,a-ke-te-re“, běžně překládané jako kupec. Milani se však domnívá, že jiný význam tohoto slova je zdravotní sestra či pečovatelka. ${ }^{13}$ Tabulka Py Vn $1314^{14}$ byla objevena v místnosti č. 99 (Room 99) a na jejím prvním řádku je zmíněn výraz

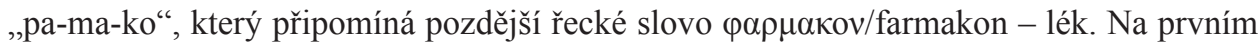
rádku je zároveň napsáno slovo „a-wa-ra-ka-na-o“, které by teoreticky mohlo znamenat jméno lékaře či obecně toho, kdo lék připravil. Celé sdělení na prvních třech řádcích je interpretováno jako příprava léčiva, snad lékařem A-wa-ra-ka-na-o, založeného na léčivých rostlinách, a jeho donesení osobou (jménem?) Wo-to-mo. Tato tabulka dokazuje existenci osoby, patrně specialisty (farmaceuta?), znalé pěstování, vlastností a účinků léčivých rostlin. Zároveň z jejího textu jasně vyplývá, že léčivé rostliny a z nich vyrobené léky

8 Viz např. M. Ventris - J. Chadwick, Documents, s. 123, 547; Y. Duhoux - A. M. Davies, A Companion, I, s. 139; Frederico Aurora - Asgeir Nesøen - Damir Nedić - Heidi LøKen - Andrea Bersi (eds.), DAMOS Database of Mycenaean at Oslo, Oslo 2013, <https://www2.hf.uio.no/damos/> (10. 11. 2017); Robert ArNotT, Healers and Medicines in the Mycenaean Greek Texts, in: Demetrios Michaelides, Medicine and Healing in the Ancient Mediterranean World, Oxford - Philadelphia 2014, s. 44-46; Nicolas Ch. STAMPOLIDIS - Yorgos Tassoulas (eds.), Hygieia: Health, Illness, Treatment from Homer to Galen, Athens 2014, s. 148.

9 Viz např. M. Ventris - J. Chadwick, Documents, s. 2; F. Aurora et al., DAMOS.

10 M. Ventris - J. Chadwick, Documents, s. 158, 418, 529.

11 L. R. Palmer, The Interpretation of Mycenaean Greek Texts, Oxford 1963, s. 405-511.

12 Viz např. L. R. PAlmer, The Interpretation, s. 144, 280; F. Aurora et al., DAMOS.

13 Celestina Milani - Onofrio Carruba, La farmacia nel mondo minoico-miceneo ed egeo-anatolico. Atti del seminario tenuto a Chieti il 18. 4. 85, presso l'università degli studi 'G. d'Annunzio'facoltà di lettere, Chieti 1986, s. 35.

14 Viz např. M. Ventris - J. Chadwick, Documents, s. 505; Richard Janko, Herbal Remedies at Pylos, Minos 17/1, 1981, s. 30-34; F. Aurora et al., DAMOS; R. Arnott, Healers, s. 47; N. Ch. Stampolidis - Y. Tassoulas (eds.), Hygieia, s. 149. 
byly organizovaně skladovány v prostorách $\mathrm{k}$ tomu určených. Není zcela zřejmé, zda byly takové rostliny také úmyslně pěstovány nebo alespoň sbírány, ale dá se to předpokládat. Nejasným také zůstává, kdo byl onen dodavatel (wo-to-mo) léčivých rostlin a kdo lék připravoval. Samozřejmě mohl lék připravit lékař, snad dokonce onen i-ja-te, zmíněný na tabulce Py Eq 146, který se zároveň mohl jmenovat A-wa-ra-ka-na-o (pak by tento specialista byl druhým z dvou nejstarších jménem známých řeckých a evropských lékařù). Wo-to-mo zase mohl být jeho asistentem, snad i ošetřovatelem, který pomáhal s př́pravou léků a při některých léčebných zákrocích. Jako lék či léčivo je také někdy překládán výraz „a-ke-a“ na tabulce Py Vn 130, ${ }^{15}$ opět pocházející z Archivního komplexu. ${ }^{16}$ Lék má být podle textu uchováván v nějaké (větší) nádobě.

Na tabulkách popsaných lineárním písmem B z Knóssu, Pylu a Mykén jsou také zmiňovány i samotné rostliny, nejčastěji koření, které mají i léčivé účinky nebo využití. ${ }^{17}$ Nejvíce jich je zaznamenáno na sérii tabulek Ge z Mykén. ${ }^{18}$ Konkrétně jde o celer, koriandr, kmín, šáchor, fenykl, fíky, malabarský citrus/voňatku citronovou, kosatec, řeřichu, mátu, cibuli, polej, růži, šafrán, světlici, šalvěj, sezam, řečík terebinth a sléz. Podle Wylocka byly vzhledem $\mathrm{k}$ jejich malým množstvím zaznamenaným na tabulkách cíleně sbírány a užívány $\mathrm{k}$ léčebným účelům. ${ }^{19}$ Bohužel tyto rostliny, které mají pro zdraví různé prospěšné účinky (napřr. pro gastrointestinální trakt - polej, koriandr, kmín, fenykl a celer dobře fungují proti nadýmání), bývají zmiňovány $\mathrm{v}$ nemedicínských kontextech, nejčastěji ve spojení s produkcí parfémovaného oleje, který byl v mykénském Řecku produkován i exportován ve velkém množství. ${ }^{20}$ Léčebné využití takového oleje není ve studovaném období doloženo, ale nelze ho vyloučit. I dnes je totiž na řeckém venkově dosti rozšiřrena produkce domácích léčiv ve formě roztoku olivového oleje s vyluhovanými nebo rozdrcenými sušenými léčivými bylinami. $Z$ textů $\mathrm{v}$ lineárním písmu $\mathrm{B}$ jsou také známy některé potraviny, které mají zdraví prospěšné či př́imo léčivé účinky. Dobrým př́íkladem může být med, zmíněný na tabulce $\mathrm{Kn} \mathrm{Gg} 705$ z Knóssu (z archeologické fáze pozdně mínojská IIIA2 /late/, 2. polovina 14. století př. Kr.). ${ }^{21}$ Ta zaznamenává oběti ve formě nádob plných medu bohyni porodu Eileithyi v lokalitě Amníssos. Med je znám jako prírodní antibiotikum a mohl být užíván i jako př́sada do mastí. Uvedená tabulka je důležitá $i$ tím, že je na ní vůbec poprvé uvedeno konkrétní jméno božstva spjatého s medicínou a zdravím.

\subsection{Literární prameny z „temného“ období}

Literárními prameny z tohoto období jsou pouze básně - především epické (homérské eposy a Hésiodova díla, některé tzv. homérské hymny), ale i lyrické (některé tzv. homérské hymny). Homérské eposy Ílias a Odysseia jsou nejstaršími evropskými literárními díly. Obě zaznamenávají části tzv. trójského cyklu - soubor mýtů týkající se příčin vypuknutí trójské

15 Viz např. L. R. PALMER, The Interpretation, s. 139, 160, 268.

16 C. Milani - O. Carruba, La farmacia, s. 34.

17 Viz např. jejich přehled v R. ARnOTT, Healers, s. 48, tab. 6.1.

18 Viz např. F. Aurora et al., DAMOS.

19 Michel Wylock, Les aromates dans les tablettes Ge de Mycènes, Studi micenei ed egeo-anatolici 15, 1972 , s. $105-146$.

20 Viz např. M. Ventris - J. Chadwick, Documents, s. 219-231; Cynthia W. Shelmerdine, The Perfume Industry in Mycenaean Pylos, Göteborg 1985.

21 Viz např. M. Ventris - J. Chadwick, Documents, s. 206; F. Aurora et al., DAMOS. 
války (výpravy spojené řecké armády proti městu Tróji), její desetiletý průběh a návrat nejvýznamnějších hrdinů domů do Řecka. Obě básně líčí mýty a pověsti závěru doby bronzové, podané ale optikou „temného věku“ (tedy rané doby železné). Archeologicky homérské reálie nejlépe odpovídají 8 . století př. $\mathrm{Kr}^{22}$ Vzhledem $\mathrm{k}$ válečné tematice je pro dějiny lékařství dủležitějším pramenem Ílias. Je v ní popsáno celkem 143 poranění (lehkých, vážných i smrtelných) a použito asi 150 anatomických termínů, z nichž řada stále existuje v řeckém jazyce (a $\mathrm{z}$ něj mnohdy přešla i do ostatních jazyků). Na tomto vysokém počtu popisů zranění je možné doložit stav anatomických znalostí, počátky somatické terminologie, úlohu a postavení lékaře, vlastní léčebnou praxi a používaná léčiva. Jsou zde také poprvé jmenovány osobnosti, které $\mathrm{v}$ řecké tradici patří mezi legendární lékaře. Je zde např. poprvé zmíněn Asklépios, ${ }^{23}$ který ještě během archaického období začíná být uctíván a v 5. století př. Kr. se - jako syn boha Apollóna - definitivně stane hlavním léčebným božstvem antiky. V Odyssei se také kromě zranění či smrti v boji setkáme se zraněním způsobeným při lovu (dnešní terminologí řečeno „při adrenalinovém sportu“). Odyssea v mládí zranil kanec, který mu na stehně nad kolenem klem vytrhl kus masa. ${ }^{24}$ Př́buzní mu samozřejmě poskytli pomoc, rána se zahojila, ${ }^{25}$ ale zůstala mu charakteristická jizva, podle které ho po jeho návratu z Tróje poznala chůva. U Homéra je také prezentován koncept, že nemoc je božím trestem člověku za přečin proti zavedenému řádu. ${ }^{26}$

S Homérovým jménem bývají již od antiky také spojovány tzv. homérské hymny. ${ }^{27}$ Jde o třicet tři hexametrických skladeb různého obsahu, zapsaných pravděpodobně až mezi 5. a 3. stoletím př. Kr. U některých z nich se ale někdy předpokládá starší původ (snad v 7. -5 . století př. Kr.) a některé tradice a rukopisy je také připisují i jiným autorům, např. Orfeovi, Kallimachovi nebo Proklovi. Pro dějiny lékařství jsou důležité hymnus č. II, $\mathrm{Na}$ Apollóna, ${ }^{28}$ kde je zmíněna bohyně porodu Eileithyia (uctívaná především na Krétě), ${ }^{29}$ hymnus č. X, Na Athénu, ${ }^{30}$ a hymnus č. XXII, Na Asklépia, ${ }^{31} \mathrm{v}$ němž je tento bůh již vzýván jako syn Apollóna a smrtelné ženy Korónidy. V hymnu Na Athénu je popsáno Athénino zrození z hlavy jejího otce Dia, odkud vyskočila v plné zbroji. U jiných autorů, především v díle Theogoniá (Zrození bohů) básníka Hésioda, ${ }^{32}$ tvořícího okolo roku 700 př. Kr., byla tato událost popsána s většími detaily, z čehož lze usoudit, že šlo vlastně o specifický

22 Obecně o homérských eposech a cyklu viz např. Luciano CANFora, Dějiny řecké literatury, Praha 2001, s. 29-54.

23 Ílias, zpěv IV, verš 194 (Homéros, Ílias, přeložil Otmar VAŇORnÝ, Praha 2007): „[...] Asklépia, jenž výborným lékařem býval $[\ldots]^{\text {“. }}$.

24 Odysseia, zpěv XIX, verše 449-451 (Homéros, Odysseia, přeložil Vladimír ŠRÁMEK, Praha 1940): „Ten vrhl se na něho bokem a vytrhl mu kus masa nad kolenem, zuby však nepronikly až na kost.“

25 Odysseia, zpěv XIX, verše 455-458: „Doběhli strýci. Ránu vítězi obvázali a zaříkali mu proud černé krve.“

26 Viz např. Ílias, začátek zpěvu I, kde bůh Apollón sesílá na Řeky mor, protože byl zneuctěn jeho kněz. V další části trójského cyklu (už ale nezachyceném v Íliadě) bohové také seslali šílenství na hrdinu Aianta, který v záchvatu pobil stádo ovcí. Po procitnutí pod tíhou hanby spáchal sebevraždu.

27 Viz např. L. CANFora, Dějiny, s. 54.

28 Homérské hymny, s. 39-58 (Homérské hymny. Válka žab a myší, přeložil Otakar SmRčKa, Praha 1959).

29 Homérské hymny, s. 42-43. Obecně o bohyni viz např. Semeli Pingiatoglou, Eileithyia, Würzburg 1981.

30 Homérské hymny, s. 99.

31 Homérské hymny, s. 111: „Asklépia nejprve opěvám, lékaře chorob, Apollónova syna, jejž zrodila Korónis jasná, dcera Flegya krále, kde Dótijská rovina zkvétá, velkou útěchu lidstvu, by konejšil bolesti trapné. Tak již, pane, bud' zdráv! Svou písní vroucně tě vzývám. “

32 Viz např. L. CANFora, Dějiny, s. 55-69. 
lékařský zákrok. ${ }^{33}$ Bůh řemesel Héfaistos totiž Diovi naštípl sekyrou lebku, odkud vystoupila Athéna. Na poraněnou Diovu lebku pak byly přikládány léky, takže (protože šlo o božskou hlavu) brzy zcela srostla.

\section{Rozbor}

Vzhledem k mnohdy fragmentárnímu stavu dochování tabulek jsou čtení a interpretace textů psaných lineárními písmy A a B jen velice obtížné a snadno může dojít $\mathrm{k}$ nepochopení. Pro dějiny medicíny sledovaného období jsou nejdůležitější záznamy o lékaři (i-ja-te) a léčivých př́pravcích (pa-ma-ko), vyráběných patrně z bylin s léčivými účinky, které byly sbírány a uchovávány v palácových skladištích. Je dost dobře možné, že na tabulkách z Pylu jsou poprvé $v$ evropských dějinách uvedena jména lékařu (či spiše léčitelů) - [...] me-no a A-wa-ra-ka-na-o. Zároveň také tyto tabulky potvrzují existenci pomocného zdravotnického personálu, snad jakéhosi ošetřovatele či mastičkáře. Náboženský aspekt prehistorické medicíny dokládá a ozřejmuje tabulka z Knóssu zmiňující bohyni porodu Eileithyi.

Ílias je nejstarším literárním zdrojem somatické terminologie té doby, což ukazuje nejen lékařské znalosti, ale i vývoj př̀dstav o fungování lidského těla, respektive jeho částí. V této souvislosti je zajímavou skutečností, že somatické termíny se vyskytují nejen v bojových scénách, ale jsou uváděny i v rámci denních a rituálních aktivit, při př́sahách i proklínání. Detailní popisy bojových scén - a zvláště jejich výsledku, tj. zranění nebo smrti jednoho $\mathrm{z}$ bojovníků - ukazují poměrně přesné anatomické znalosti o určitých částech těla i některých orgánů, ba někdy i jejich funkcí (např. ve scéně, kdy Achilleus zabíjí Hektora probodnutím krku, ale mimo průdušnici - básník si uvědomoval, že měla nějakou souvislost s mluvením). ${ }^{34} \mathrm{~V}$ určitém smyslu byl také pochopen význam některých orgánů a krve pro zachování života. (Její existence u člověka také byla jedním z hlavních rozdílů mezi smrtelnými lidmi a nesmrtelnými bohy, kteří místo krve mají jakousi tekutinu „íchor“.) Dobře jsou popsány i somatické reflexe některých emočních pochodů, např. strachu (člověku buší srdce, třese se atp.). V několika scénách jsou také vylíčeny léčebné zákroky poté, co byl některý bojovník zraněn. Ve dvou př́padech zraněnému hrdinovi poskytl první pomoc spolubojovník (Sthenelos vytáhl Diomédovi z ramena šíp, který ho zranil;;3 Sarpedónovi vyndal ze stehna oštěp Pelagón ${ }^{36}$ ), což svědčí o tom, že $\mathrm{v}$ případě zranění museli vojáci umět pomoci elementárními lékařskými úkony sobě i svým spolubojovníkủm. Jinak samožrejmě kvalifikované ošetření prováděli lékaři, jimiž jsou v Íliadě Macháón a Podaleiros, synové Asklépiovi. V prŕípadě potřeby byl pro ně poslán posel. Tak tomu bylo, třeba když byl Mene-

33 Celkově viz Karl KerénYi, Mytologie Řeki̊, I, Přiběhy bohů a lidi, Praha 1996, s. 94-95.

34 Ílias, zpěv XXII, verše 324-329: ,Vidět bylo jen krk, jenž od pleci dělí se klíčem; jícen, kde život lidský je rychlé záhubě vydán. Tam, jak na něj se hnal, jej probodl Achilleus slavný: rázem měkkou šijí skrz naskrz proniklo ostří. Jasan kováním těžký však neprot’al průdušnou rouru, pročež promluvit mohl a ještě mu odvětil slovy."

35 Ílias, zpěv V, verše 95-113: „Slavný Lykáonovec jak hrdinu před sebou spatřil, jak tam po pláni zuří a honí před sebou šiky, ihned na Dioméda svým křivým zamířil lukem, jak se tak kupředu řítil, a v pravé plece ho ranil, zasáhnuv krunýře plát - jím ostrá prolétla střela: pronikl hrot skrz naskrz, a krunýř barvil se krví. [...] Tak tam s jásotem mluvil - však šíp jej nezabil rychlý, hrdina za své koně a za vůz ustoupiv rychle, stanul a k Sthenelu děl, jenž pocházel od Kapanéa: ,Honem, Sthenele můj, ted’ sestup se svého vozu, abys z ramene mého mi ostrou vytáhl střelu!‘ Takto mu raněný pravil, a Sthenelos seskočil s vozu: přišel a rychlou střelu mu celou vytáhl z plece, krev pak stříkala ven skrz pletenou rekovu sukni.“

36 Ílias, zpěv V, verše 660-695. 
láos zraněn šípem. ${ }^{37}$ Macháón a Podaleiros jsou však řadovými vojáky a normálně se účastní bojů. Nejsou to tedy pouze ošetřovatelé poskytující první pomoc na bojišti nebo lékaři pracující na ošetřovně za bitevní linií. Jejich léčitelské či ranhojičské umění je pouze jakousi nadstandardní dovedností, i když si velitelé dobře uvědomují jejich důležitost pro celé vojsko a vyjadřují obavy o Macháónův život, když je zraněn. ${ }^{38}$ Ale ani toto není pro velitele důvodem, aby se oba bratři neúčastnili bojových operací. Ve dvou pasážích eposu je pak bez bližší specifikace uvedeno, že lékaři ošetřují pacienta, ${ }^{39}$ respektive jim $\mathrm{k}$ tomu byl dán rozkaz. ${ }^{40}$ Macháón a Podaleiros také ani nemuseli mít $\mathrm{v}$ dnešní terminologii a chápání „úplné lékařské vzdělání“. V Íliadě vystupují pouze jako ranhojiči, respektive váleční chirurgové. $V$ eposu totiž např. není žádná zmínka, že by se nějak angažovali při snaze o potírání morové epidemie, kterou v řeckém táboře rozšíríil bůh Apollón jako trest za urážku jeho kněze Chrýsa. ${ }^{41}$ Na základě všech těchto skutečností by se mohlo překvapivě zdát, že během prvních staletí 1. tisíciletí př. Kr. ještě nemuselo lékařské umění fungovat jako samostatné povolání - i když některé ostatní prameny (především antropologické a archeologické) nasvědčují spiše opaku. Na druhou stranu, v jedné pasáži v Odyssei je léčitel uveden jako osoba se speciálními znalostmi (podobně jako např. řemeslníci), jejíž prínos je však důležitý pro celou komunitu - mimo jiné tím, že léčitelé (na rozdíl od většiny ostatních profesí) bývali běžně vpouštěni do domácností. ${ }^{42}$

Jako prvotní lékař - učitel a v jistém smyslu i zakladatel jakési lékařské či ranhojičské školy první pomoci a válečné chirurgie - je na několika místech jmenován Kentaur Cheirón, napůl člověk a napůl kůň, který žil v Thessalii ve středním Řecku. Ten podle eposu vyučil lékařskému umění nejprve Asklépia, a poté i některé další hrdiny, především Achillea. Ten pak naučil ošetřovat rány i svého nejlepšího př́itele Patrokla. Dokonce hned ve dvou pasážích je vylíčen Patroklos při ošetřování zraněných spolubojovníků ve stanu ${ }^{43}$

37 Ílias, zpěv IV, verše 184-219. Meneláos zasažený šípem do pasu uklidňuje svého bratra Agamemnóna, který posílá Talthybia pro lékaře Macháóna: „Nemeškej, odejdi rychle, at' Macháón přijde co nejdřív, zrozený z Asklépia, jenž výborným lékařem býval [...].“ Macháón po svém příchodu zranění ošetřil: „[...] Macháón, podobný bohu, se postaviv do jejich středu, z opasku přilehlého se snažil vyvléknout střelu. Jak však táhl ji ven, v tom háčky se zlomily ostré. Proto radš opasek třpytný mu odepjal, vespod pak zase podpásník jeho a pás, jejž robili kovářští muži. Když pak prohlédl ránu, kde ostrá se zaryla šipka, vyssáv veškeru krev, hned znalecky přikládal léky, hojivé, které Cheirón kdys daroval z přátelství otci.“

38 Îlias, zpěv XI, verše 504-519: „Tehdyž Achajci slavní by nijak necouvli z cesty, kdyby v tom Macháóna chot' Heleny kadeří krásných, slavného vladaře lidu, byl nevzdálil z chrabrého boje, ostrým trojhrotým šípem ho v pravé postř̌eliv plece. O něho veliký strach jal Danay dýšící silou, kdyby se zvrátil zápas, by nějak ho nepř́itel nesklál. Z příčiny té král krétský se k slavnému Nestoru ozval: ,Nestore, Néleův synu, ty velká Danaů pýcho, pospěš a vystup na vůz, a raněný Macháón k tobě, k lodím pak úprkem žeň své spřežení jednokopytné, nebot' lékařský muž jest cenou za mnoho jiných: umí vyříznout šípy a přiložit hojivé léky. ‘ Řekl, a bez dlení kmet byl srozuměn, Gerénský jezdec, ihned vystoupil na vůz, a raněný Macháón k němu, zrozený z Asklépia, jenž výborným lékařem býval.“

39 Ílias, zpěv XVI, verše 25-29: „Střelen je statečný rek, syn Týdeův, mohutný silák, boden je vladyka mužstva, i Odysseus oštěpem slavný, rovněž i Euaimonovec jest postřelen do stehna šípem. Lékaři, zběhlí v lécích, je nyní ošetřit hledí, léčíce jejich rány.“

40 Ílias, zpěv XIII, verše 213-214: „Toho [zraněného spolubojovníka] mu přinesli druzi a rek dav lékařům rozkaz, spěchal do stanu sám, vždyt' mínil se do boje vrátit.“

41 Ílias, zpěv I, verše 10-11, 44-56.

42 Odysseia, zpěv XVII, verše 380-387: „Leda by to byl někdo, kdo pracuje pro celou obec: stavitel lodí, zaklínač moru, věštec nebo zpěvák. Ty každý volá po celém světě.“

43 Ílias, zpěv XV, verše 390-394: „Patroklos za doby té, když trójské i danajské mužstvo opodál rychlých lodí kol ochranné válčilo hradby, seděl ve stanu zatím a bavil hovorem družným mužného přítele svého a na jeho bolestnou ránu přikládal hojivý lék, jenž konejší bolesti černé.“ 
přičemž v jednom př́ípadě dokonce provádí komplikovaný chirurgický zákrok (jaký je běžně vykonávaný jen lékaři Macháónem a Podaleirem). ${ }^{44} \mathrm{~V}$ prvním př́padě se při aplikaci léku družně baví se zraněným, což je třeba vnímat jako důležitý psychologický faktor, který má uklidnit pacienta. Tyto pasáže také dobře popisují průběh vlastního chirurgického zákroku. Nejprve je naříznuta kůže okolo proniklého hrotu šípu či oštěpu, hrot je vyjmut, rána je vymyta a zbavena krve a pak je přiloženo léčivo rostlinného původu $\mathrm{s}$ analgetickými účinky. Jde tedy o chirurgický zákrok spadající do válečné chirurgie. $Z$ toho se zdá, že ke standardnímu kurikulu vzdělání vysoce postavených mladých mužủ, často božského původu, patřilo i ranhojičství a určité botanické znalosti, aby byli schopni vyrobit a podat lék rostlinného původu. Jak je uvedeno výše, tabulky s lineárním písmem B dokládají, že $\mathrm{v}$ pozdní době bronzové byla pěstována či sbírána celá řada rostlin s léčivými účinky. $V$ jedné pasáži v Odyssei dokonce bůh Hermés dává Odysseovi rostlinu, která ho ochrání před působením kouzel.$^{45} \mathrm{~V}$ Odyssei jsou ještě zmíněny další dvě látky se speciálním účinkem. Jde o lék se silnými antidepresivními účinky (opět rostlinného původu), který Helena přimíchá do vína, ${ }^{46} \mathrm{a}$ jed, jímž se napouštěji šípy. ${ }^{47}$ To všechno dokazuje velmi dobré botanické znalosti Řeků v prehistorickém i raně historickém období.

V Íliadě je také na dvou místech zmíněna, respektive jsou zmíněny bohyně porodu Eileithyie - jméno Eileithyia (znamenající „Přicházející“) je totiž v obou případech uvedeno v plurálu. ${ }^{48}$ Podle tohoto eposu šlo o dcery bohyně Héry, sestry a manželky nejvyššího boha Dia. Na jednom místě je uvedena v souvislosti s porodními bolestmi ${ }^{49}$ na tom druhém je připomenuta její moc uspíšit či oddálit porod. ${ }^{50} \mathrm{~V}$ Odyssei je zmíněna její posvátná jeskyně u krétského Amníssu. ${ }^{51}$

V homérských eposech je sice nemoc považována za boží trest, ale zároveň je na několika místech - stejně jako u Hésioda - možné najít i zmínky o léčivém božstvu jménem Paián. ${ }^{52}$ Toto božstvo (,lékař, který zná léky na všechny problémy“) později v archaickém a klasickém období splynulo s bohem Apollónem, který dostal jméno Paián jako přízvisko

44 Ílias, zpěv XI, verše 828-848: „Ty však mě zachraň a k černé lodi mě zaved', ze stehna vyřízni šipku a krev hled' vymýti temnou na ráně teplou vodou a přikládej hojivé léky, účinné, jakým právě ses naučil od Achillea, jehož vyučil Cheirón, všech Kentaurů nejvzdělanější - nebot' lékaři naši, rek Macháón, Podaleiros - Macháón ve stanu jest, jak myslím, stižen jsa ranou, pročež lékaře sám jest potřeben výborného, druhý na pláni trójské zas prudkému zápasu čelí. [...] Ten prostřel hovězí kůže. Položiv jej, vzal nůž, jímž vyřízl ze stehna šipku, ostrou, velice ostrou, a hořký přiložil kořen hojící bol, dřív rozemnuv jej. Ten kořen pak všecku nadobro ztišil trýzeň, krev ustala, rána pak zaschla.“

45 Odysseia, zpěv X, verš 302-304: „,Domluvil Argův vrah, vytrhl ze země čarovnou bylinu, podal mi ji a ukázal vlastnosti její. Kořen byl celý černý, květy pak bílé jak mléko.“

46 Odysseia, zpěv IV, verše 220-229: „Heléné, Diova dcera, si vzpomněla však a vhodila do vína, z kterého pili, lék proti hoři, hněvu a strastem. Napije-li se kdo vína, jež s kouzlem tím v měsidle smícháno bylo, nezkropí toho dne slza mu lící, i kdyby otec či matka mu skonali právě, a kdyby na vlastní oči zřel bratra či syna umírat mečem. Takové moci byl čarovný kořen $[. .$.$] .“$

47 Odysseia, zpěv I, verše 258-261: „Dojel si k Ílovi na rychlé lodi pro jedovaté št’ávy, jimiž by napustil kovové šípy. Ílos mu nedal jed, boje se věčných bohů, otec však dal mu ty štávy, protože mu byl přítelem zdávna.“

48 Ílias, zpěv XI, verše 269-271; zpěv XIX, verš 119.

49 Ílias, zpěv XI, verše 269-271: „Jako se rodička svíjí, jsouc raněna bolesti šípem, ostrým, jejž Eileithýie jí seslaly, budíce bolest, bohyně Héry to dcery, jež trpké bolesti nosí [...].“

50 Ílias, zpěv XIX, verš 119: ,[...] Alkménin zdržela porod a vzdálila Eileithýie [...].“

51 Odysseia, zpěv XIX, verš 188 : „Unikl sotva bouři a kotvil v nejisté zátoce při ústí Amníssu u sluje Eileithyiny.“

52 Viz např. Ílias, zpěv V, verše 401 a 899; Odysseia, zpěv IV, verš 231. 
(epiteton) a měl určité léčivé schopnosti. ${ }^{53} \mathrm{~S}$ největší pravděpodobností také proto mezi 8. a 6. stoletím př. Kr. docházelo ke ztotožňování Apollóna s Asklépiem, který se nakonec v náboženských představách a mytologii stal Apollónovým synem. ${ }^{54}$ Asklépios se pak od 5. století př. Kr. stal hlavním léčebným božstvem antiky (po jeho přijetí Římany do jejich pantheonu v helénistickém období) a dodnes je považován za patrona lékařů. ${ }^{55}$

\section{Závěrem}

Literárních pramenů ze sledovaného období je málo a navíc je jejich interpretace dosti složitá. Je tomu tak z více důvodů, fyzických i metodologických. Z prehistorického období jde o texty v lineárním písmu A a B, které zaznamenávají jen kusé informace hospodářského charakteru. Navíc bohužel někdy není po lingvistické stránce zcela jisté ani jejich správné čtení. $\mathrm{V}$ „temném“ období jsou dostupné literární prameny uměleckými básnickými díly. Jejich primárním účelem je vyprávět př́běhy nebo uctít božstva, př́ípadně vyjádřit pocity včetně úcty. Žádný ze zde diskutovaných písemných pramenů tedy není standardním historickým, respektive medicínsko-historickým pramenem, a obsahuje tak vždy pouze minimum informací vypovídajících o úrovni medicíny své či dřívější doby. Je tedy nutné je nejprve správně pochopit a interpretovat na pozadí archeologické reality doby jejich vzniku a všechny př́imé či neprímé zmínky o zdraví, lékařství i léčení v nich postupně najít.

I přes všechny tyto těžkosti literární prameny poskytují pro některé části období sledovaného v tomto př́spěvku sice velmi kusé, ale důležité a rozmanité informace. Díky tomu jsou známy nejen některé detaily ozřejmující formování náboženských představ souvisejících se zdravím a léčením, ale především takové, které se týkají vlastní lékařské praxe, léčebných prostředků i samotných lékařů (včetně pravděpodobných jmen konkrétních léčitelů) a pomocného zdravotnického personálu.

\section{TOMÁŠ ALUŠíK}

\section{Literarische Quellen zur griechischen Medizin der prähistorischen Zeit und des „dunklen“ Zeitalters (bis 600 v. Chr.)}

\section{ZUSAMMENFASSUNG}

Der Aufsatz behandelt literarische Quellen zur Entwicklung der griechischen Medizin der prähistorischen Zeit (Bronzezeit, vor allem das 2. Jahrtausend v. Chr.) und des sog. ,dunklen“ Zeitalters (bis 1050 v. Chr.) bis 600 v. Chr. Bei den Texten aus der Bronzezeit handelt es sich um mehrere Texte (vor allem auf Tontäfelchen), die in Silbenschrift, dem sog. Linear A und B geschrieben sind. Texte in dieser Schrift haben jedoch rein wirtschaftlichen bzw. administrativen Charakter. Aus dem ,dunklen“ Zeitalter lässt sich eine gewisse Menge an Informationen

53 Viz např. Vassileios K. Lambrinoudakis, Theurgic Medicine, in: N. Ch. Stampolidis - Y. Tassoulas (eds.), Hygieia, s. 17.

54 K. KerÉnyi, Mytologie Řeki̊, I, s. 111-113; V. K. LambrinoudaKis, Theurgic Medicine, s. 30.

55 Viz např. Karl KerÉnyI, Asklepios: Archetypal Image of the Physician's Existence, New York 1959; Jürgen W. Riethmüller, Asklepios: Heiligtümer und Kulte, Heidelberg 2005; Alice Walton, Asklepios: The Cult of the Greek God of Medicine, Reprint of the 1894 Edition, Whitefish 2006; Bronwen L. WickKISER, Asklepios, Medicine and the Politics of Healing in Fifth-Century Greece: Between Craft and Cult, Baltimore 2008. 
über medizinische Kenntnisse und Heilverfahren aus Kunstwerken (Poesie) gewinnen, vor allem den homerischen Epen, aber auch aus den sog. Homerischen Hymnen und aus Hesiod.

Für die Geschichte der Medizin in prähistorischer Zeit sind am wichtigsten die Aufzeichnungen über einen Arzt (i-ja-te) und über Heilmittel (pa-ma-ko), die offensichtlich aus heilwirkenden Kräutern zubereitet sind, welche man sammelte und in Palastmagazinen aufbewahrte. Es ist gut möglich, dass sich auf den Täfelchen aus Pylos erstmals in der europäischen Geschichte die Namen von Ärzten (oder besser gesagt von Heilern) finden: „[...] me-no“ und „A-wa-ra-ka-na-o“. Der religiöse Aspekt der prähistorischen Medizin wird durch ein Täfelchen aus Knossos, das die Göttin der Geburt, Eileithyia, erwähnt, belegt und verdeutlicht.

Im „dunklen“Zeitalter beschreiben die Homerischen Epen zahlreiche Verwundungen und mehrmals auch einen medizinischen Eingriff, vor allem in der Illias. Diese ist außerdem die älteste literarische Quelle für die somatische Terminologie jener Zeit und nennt an zwei Stellen ebenfalls die Göttin der Geburt, Eileithyia. In der Odyssee wird die heilige Höhle dieser Göttin bei Amnissos auf Kreta erwähnt. Insgesamt gibt es nur wenige literarische Quellen aus dem untersuchten Zeitraum; zudem ist deren Interpretation ziemlich schwierig, was auf mehrere Gründe, auf physische wie methodologische, zurückzuführen ist. Bei den Texten aus prähistorischer Zeit handelt es sich um Texte in Linear A und B, die ihrem Charakter nach nur dürftige Informationen wirtschaftlichen Charakters sind. Darüber hinaus ist auch ihre richtige Lesung aus linguistischer Sicht nicht immer ganz sicher. Für das „dunkle“ Zeitalter bilden epische Kunstwerke die zugänglichen literarischen Quellen. Ihr primärer Zweck ist es, Geschichten zu erzählen oder Götter zu verehren, gegebenenfalls Gefühlen und Ehrbezeugungen Ausdruck zu verleihen. Keine der hier diskutierten schriftlichen Quellen kann also als standardmäßige historische bzw. medizinhistorische Quelle erachtet werden, zudem enthalten sie stets nur ein Minimum an Informationen über das Niveau der Medizin ihrer Zeit oder früherer Zeiten. Sie müssen also zunächst richtig verstanden und vor dem Hintergrund der archäologischen Realität ihrer Entstehungszeit interpretiert und alle in ihnen enthaltenen direkten bzw. indirekten Äußerungen über Gesundheit, Medizin und Behandlung allmählich gefunden werden.

Trotz dieser Schwierigkeiten liefern die literarischen Quellen für bestimmte Zeiträume zwar sehr dürftige, aber doch wichtige und vielseitige Informationen. Dank ihrer kennen wir nicht nur einige Details, die die Herausbildung religiöser Vorstellungen im Zusammenhang mit Gesundheit und medizinischer Behandlung erhellen, sondern vor allem solche, die die eigentliche medizinische Praxis, die Heilmittel sowie die Ärzte selbst (einschließlich wahrscheinlicher Namen konkreter Heiler) und das medizinische Hilfspersonal betreffen.

Deutsche Übersetzung Wolf B. Oerter

\author{
Tomáš Alušik \\ Ústav dějin lékařství a cizich jazyků \\ 1. Lékařská fakulta Univerzity Karlovy, Praha \\ tomas.alusik@lf1.cuni.cz
}

